\title{
Agricultural Vocational Education in Developed Countries with Reference to Beijing Urban Agriculture Development
}

\author{
Wang Xiaodi, Liu Yanjun, Meng Jie, Zhang Yuan \\ International Information Research Department \\ Beijing Institute of Science and Technology \\ Beijing, China \\ wangxd@bjstinfo.com.cn
}

\begin{abstract}
The goal of urban agriculture construction in Beijing is adhere to the economic, political, cultural and social construction around development theme. Moreover, through innovating as driving force to promote reform development, Beijing agricultural vocational education should construct system and mechanism of balancing urban and rural development, coordinate urban and rural economic and social development and the public harmonious development. Establishment of new rural construction goal aims to put forward new challenges and demands for agricultural vocational education. Firstly, authors make research on agricultural vocational education development in developed countries. Secondly, authors make a comparative study on agricultural vocational education system and the national policy support in developed countries. Finally, authors propose references to Beijing urban agriculture development, government policy support, and education structure system.
\end{abstract}

Keywords-Urban agriculture; Developed countries; Vocational education; Education structure system

\section{INTRODUCTION}

Since 1990s, urban agriculture has become a hot research topic in urban planning and agricultural development. Urban agriculture has become a hot research topic in urban planning and agricultural development. In China, with the rapid growth of city land and a series of social, economic and environmental issues, and in response to rapid urbanization, urban agriculture plays an important role in sustainable development requirements of urban construction.

The construction of urban modern agriculture is basic direction in next period for Beijing agriculture future development. Suburban agriculture is historical formation which has its own development and operation rules.Suburban economy is a special type of regional economy, Beijing suburban agriculture is a particular kind of agriculture with overall urban diversification. From commonness of world central city agricultural production development, suburban agriculture should rise to a higher level -- Urban Modern agriculture. Its essence is based on modern agricultural science and technology, financial city and suburban and rural areas to establish production modern measures, implement intensified management optimization and beautify modern agricultural production[1].

\section{URBAN AGRICULTURE DEVELOPMENT ISSUES IN BEIJING}

With deepening reform and opening up and accelerated urbanization process, Beijing urban and rural construction land has been further expand, moreover, farmland has been occupied. From 1990 to 2004, there were 408.3 thousand hm2 of cultivated land in Beijing by 1992, accounted for $24.85 \%$ of overall land area; compared within 1981, it decreased by 47.7 thousand hm2, and an average annual reduction were 4340 $\mathrm{hm} 2$. Suburb farmland had reduced by 17.1 thousand $\mathrm{hm} 2$, accounted for $31.02 \%$ of overall land area. Three plains in outer suburban district had reduced farmland by 17.1 thousand $\mathrm{hm}^{2}$, accounted for $82.44 \%$ of overall outer suburban district agricultural acreage[2].Surrounding suburban cultivated land area decrease speed was significantly higher than outer suburban district, and there was a largest reduction of farmland in suburban and outer suburban plain areas (Figure 1).

Meanwhile, because Beijing's government will focus on urban construction and rural suburbs, and unreasonable investment planning led to weak rural infrastructure, the economic development level of Beijing rural and urban area is significant difference. Farmers' income is far below urban residents, showing characteristics of the dual economic structure. However, slow development of rural construction is still in a backward state is largely due to rural population weakness of self-construction. Therefore, it is necessary for government investment in rural areas, and it is also key matter to actively develop local construction potential. Especially in rural areas, vocational skills training can play a role in rural self-construction ability development[3]. 


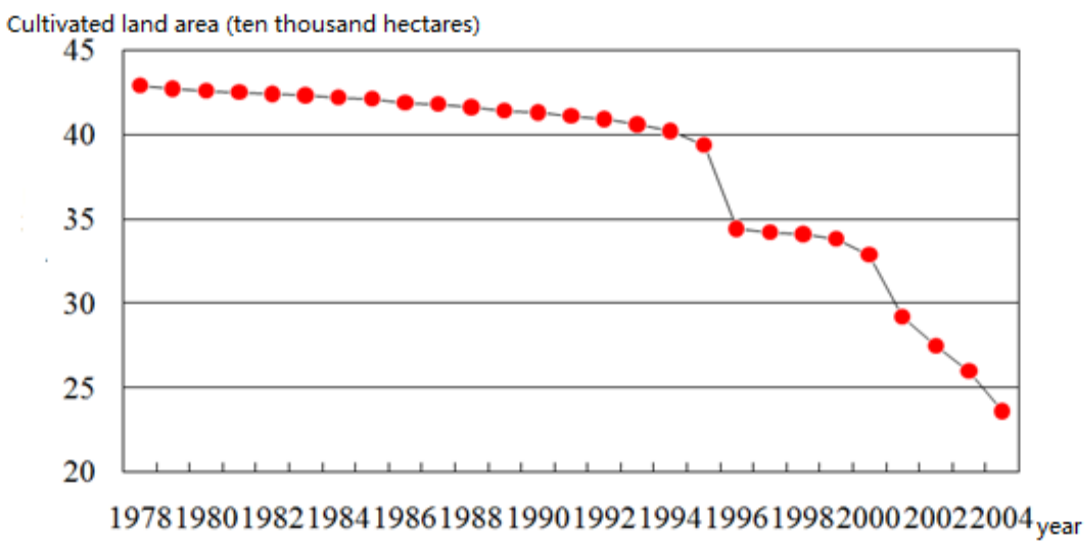

Fig. 1. A change of Beijing cultivated land area

\section{CURRENT STATUS AND ISSUES OF BEIJING AGRICULTURAL VOCATIONAL EDUCATION}

Beijing agricultural vocational education basic level is divided into three levels: career academy of agriculture, secondary vocational schools and vocational adult education.

However, compared with urban and rural construction requirements and number of agricultural vocational colleges, the quantity is inadequate. There are several issues in Beijing agricultural vocational education:

Primary agricultural vocational education is in the period of popularity. There has 1.8 million rural labors in Beijing, and there is about $1 / 6$ primary vocational education with different contents each year.

Secondary agricultural vocational education has been gradually shank. Secondary agricultural vocational education here includes full-time agricultural secondary school and adult oriented secondary vocational education includes full-time agricultural secondary school, and adult oriented secondary vocational education, and education scale has been gradually shank after 2000.

Agricultural vocational education is in growth phase.

The newly development infrastructure of agricultural vocational educationist difficult to effectively serve new rural construction.

The urban agriculture construction in Beijing is around development theme, municipal government adheres to economic, political, cultural and social construction, and innovation as a driving force to promote development reformation, construction system and mechanism. Urban and rural development theme coordinates urban and rural economic and social development, harmonious development.
New rural construction establishment aims to put forward new challenges and demands for agricultural vocational education[4].

\section{BRIEF INTRODUCTION OF FOREIGN AGRICULTURAL} VOCATIONAL EDUCATION WITH REFERENCES TO AGRICULTURAL VOCATIONAL EDUCATION DEVELOPMENT IN

\section{BEIJING}

\section{A. Briefly describe of foreign agricultural vocational education}

There has a complete education system of agricultural Vocational Education in developed countries in professional education, occupational education, technology transfer, continuing education. The education system emphasizes theory and practice, which focus on production and life develop simultaneously, create legislation and corresponding incentive policies, represent specialized management agencies and adequate funding. With strong support from the government and society, cultural and scientific quality of farmers is generally high. In order to improve peasant quality, developed countries have adopted the following measures (See Table 1 for details):

Providing formal agricultural education, and generally develop adult education, agricultural vocational and agricultural vocational and technical education.

Education forms are flexible and diverse. There are short term training courses in agricultural college, and also has agricultural extension activities.

Attaching importance to improve students' practical ability. Vocational and technical training attaches great importance student ability, especially in practical ability development. 
TABLE I. COMPARISON OF AGRICULTURAL VOCATIONAL EDUCATION SYSTEM IN DEVELOPED COUNTRIES

\begin{tabular}{|c|c|c|}
\hline Country & Education System & Labor Division \\
\hline Japan & $\begin{array}{l}\text { 1. Formal agricultural education of Ministry } \\
\text { of Education, Culture, Sports, Science and } \\
\text { Technology-Japan (MEXT); } \\
\text { 2. Cross training of agro-forestry system and } \\
\text { agricultural universities. }\end{array}$ & $\begin{array}{l}\text { 1.Agricultural Education of MEXT mainly } \\
\text { for high school and college education; } \\
2 \text {. Cross training of agro-forestry system } \\
\text { and agricultural universities mainly refers } \\
\text { to some agricultural research institutions } \\
\text { and training departments. }\end{array}$ \\
\hline $\begin{array}{l}\text { United } \\
\text { States }\end{array}$ & $\begin{array}{l}\text { Agricultural education system consists of } \\
\text { higher agricultural education, secondary } \\
\text { agricultural education and agricultural } \\
\text { extension education system. }\end{array}$ & $\begin{array}{l}\text { 1. Higher agricultural education is base of } \\
\text { agricultural colleges and universities to } \\
\text { provide high-quality talents for agriculture; } \\
\text { 2.Secondary agricultural education mainly } \\
\text { includes agricultural technical schools, } \\
\text { ordinary middle schools, and secondary } \\
\text { agricultural technology education. }\end{array}$ \\
\hline Australia & $\begin{array}{l}\text { There are three main categories of } \\
\text { agricultural education: higher agricultural } \\
\text { research education, secondary agricultural } \\
\text { extension education and universal education } \\
\text { and peasant education. }\end{array}$ & $\begin{array}{l}\text { 1.Cultivation of advanced agricultural } \\
\text { talents in universities; } \\
\text { 2.The Institute of advanced agricultural } \\
\text { education belongs to medium agricultural } \\
\text { extension application personnel education. }\end{array}$ \\
\hline Germany & $\begin{array}{l}\text { German Farmers Association }(\mathrm{DBV}) \text { is } \\
\text { responsible for agricultural vocational } \\
\text { education. }\end{array}$ & $\begin{array}{l}\text { The combination of enterprise practice and } \\
\text { vocational school theory teaching is } \\
\text { so-called "dual system", which ensure } \\
\text { students' modern agricultural technology } \\
\text { ability and understand farm production and } \\
\text { operation requirements. }\end{array}$ \\
\hline France & $\begin{array}{l}\text { The Department of Agriculture as the } \\
\text { competent department of agricultural } \\
\text { education system. Agricultural education } \\
\text { system consists of } 3 \text { parts: secondary } \\
\text { vocational and technical education, } \\
\text { advanced agricultural education and farmer } \\
\text { vocational education. }\end{array}$ & $\begin{array}{l}\text { 1.Secondaryagricultural vocational } \\
\text { education in education direction and high } \\
\text { school education stage implementation; } \\
\text { 2.Advanced agricultural education includes } \\
\text { advanced technical education, engineering } \\
\text { education and graduate education. }\end{array}$ \\
\hline
\end{tabular}

\section{B. Reference to Beijing urban agriculture development}

According to present situation and issues of Beijing agriculture occupation education development, learn from foreign practices of developed countries, as well as new rural construction and urban development of agricultural vocational education, should strengthen co-ordination and government behavior, adjust investment structure and occupation education methods, promote agricultural occupation education can better serve Beijing economic and social development[5]. All levels of government and education authorities should attach great importance to effective interaction between advanced agricultural education and rural construction. The combination of legislation and administrative allocation interfere with agricultural vocational education to support rural construction: through legal form of agricultural colleges and universities to define training objectives, course offered and funding investment, agricultural science and education can be promoted and integrated. By focus on economic development while increase financial allocations, the government can ensure government decrees can be truly implemented.
The diversification of educational structure is a common feature of higher agricultural education in developed countries. The ternary structure of agriculture structure advanced education, comprehensive university of agriculture related departments usually has bachelor degree or above and it will focus on training agricultural scientific research personnel.

Local agricultural colleges carry out vocational education and occupation education, which focus on application and promotion of agricultural education; basic agricultural occupation education is short-term training for grassroots agricultural workers and peasants."Pyramid type" structure adapts to agriculture development and rural social demand for advanced education, and at the same time, it provides a reasonable survival and development space for all kinds of agricultural colleges and universities[6].

At present, China's advanced agricultural education is dual system structural model. There has still development space in running scale of agricultural vocational education, and structure shows a "spindle type". It is difficult to fulfill agricultural economy rapid development and rural society 
demand[7]. Agriculture occupation education the structure model of the scale and level still has very large development space, showing the structure of a "spindle type", it is difficult to meet requirements of rapid development of agricultural economy and rural society. Therefore, China should vigorously develop agricultural vocational education, and constantly optimize and improve advanced agricultural education structure.

There are many successful experiences to establish occupation education system in foreign countries, such as Germany's "dual system", American Community College, can these advanced experience and our national conditions, and constantly improve the system of rural occupation education in our country[8]. There are many successful experiences in vocational education system establishment abroad. For example, such as Germany's "dual system", private enterprises cooperate with full-time vocational school for vocational education. Specifically, students of agricultural school and rural occupation will be trained in enterprises, agricultural production bases to learn related speculative knowledge and professional ethics. Students can better combine theoretical knowledge with practice, and closer to society and enterprises requirement. These advanced experiences can be combined with our national conditions to improve rural vocational education system in China.

In addition, agricultural education in developed countries includes not only regular agricultural education; also undertake implementation of continuing education, lifelong education and national education. Therefore, Beijing rural education can also undertake continuing education for rural youth. In today's lifelong education promotion, many cities have established college for senior citizens, adult education school. Therefore, we should attach importance to continuing education process in rural areas, and accelerate farmers training activities. Let peasants in China truly become a rural self-builder[9].

\section{CONCLUSION}

Efficient agricultural vocational education benefits from advanced and scientific concept of agricultural vocational education. Higher agricultural education in developed countries have accumulated a wealth of experience in improving higher agricultural education structure, training agricultural science and technology talents, accelerating innovation and popularization of agricultural science and technology achievements, developing agricultural occupation education. The development of urban agricultural vocational education in Beijing needs cooperation and support from enterprises, research institutes and institutions of higher learning. Beijing urban agriculture development needs cooperation and support from enterprises, research institutes, colleges and universities. Drawing on the typical experiences and practices of agricultural education in developed countries under the market economy conditions, we can better serve Beijing urban agriculture development.

\section{REFERENCES}

[1] [Mulder, M. Editorial: Agricultural Education and European Vocationa Education Policy Making. Journal of Agricultural Education and Extension, 2015, (21),4, 289-292.

[2] Haifeng Li. The Agricultural Vocational Education in Germany and its Implication to China [J].China Agriculture Education. 2012（5）. (In Chinese)

[3] Ashish.K.Makwana. Agricultural Education in India: Challenges and Prospects. Voice of Research Vol. 2, Issue 3,2013(90-94).

[4] Jennifer Calvin,Seburn L. Barriers and Solutions to Recruitmen Strategies of Students into Post-Secondary Agricultural Education Programs: A Focus Group Approach. Journal of Agricultural Education Volume 54, Number 4. 2013(45-57).

[5] Justin J. W. Powell, Lukas Graf, Nadine Bernhard, Laurence Coutrot \& Annick Kieffer. The Shifting Relationship between Vocational and Higher Education in France and Germany: towards convergence? European Journal of Education, Vol. 47, No. 3, 2012(405-423).

[6] Regine Berges, Ina Opitz.Urbane Landwirtschaft-Innovationsfelder für die nachhaltige Stadt?Leibniz-Zentrum für Agrarlandschaftsforschung (ZALF) e. V., 2014

[7] Jing Yang. Characteristics of Higher Agricultural Education in the USA and its Revelation [J]. Higher Agricultural Education, 2007(11).(In Chinese)

[8] Annemie Wintersa, Frans Meijersb , Marinka Kuijpersb \& Herman Baerta. Can Training Teachers Stimulate Career Learning Conversations? Analysis of Vocational Training Conversations in Dutch Secondary Vocational Education. Journal of Vocational Education and Training. 2012(1-18). (In Chinese).

[9] Hangang Bai. International Comparison of Occupational Education System. Chinese Vocational and Technical Education. 2012(12-17).(In Chinese). 